\title{
Pay Cash or Buy on Time?
}

\author{
Guan Jun Wang ${ }^{1}$ \\ ${ }^{1}$ College of Business Administration, Savannah State University, Savannah, GA, USA \\ Correspondence: Guan Jun Wang, College of Business Administration, Savannah State University, Savannah, \\ GA 31404, USA. Tel: 912-358-3416. E-mail: Wangg@ savannahstate.edu
}

Received: March 22, 2017

Accepted: April 13, 2017

Online Published: April 25, 2017

doi:10.5539/ijef.v9n5p156

URL: https://doi.org/10.5539/ijef.v9n5p156

\begin{abstract}
The conventional "buy on time or pay cash" analysis seen in some mainstream personal finance textbooks is to compare the total finance cost of the loan to the total after-tax interest earnings on savings: if the former is higher than the latter, then pay cash, otherwise buy on time. This research note points out the flaws of such conventional approaches and the better decision can be made by simply comparing the interest rate on the loan to the after tax interest rate on savings.
\end{abstract}

Keywords: buy on time, pay cash, tax, interest, time value of money

When it comes to pay for a big ticket item, such as a car, or a home project, one generally has two ways to go about it, either take an installment loan to finance the item over time, or pay cash up front. Many often have little choice but to take out a loan because they just can't afford to pay cash for an expensive item. But what if you do have the money? The common thinking is that paying with cash is better than financing to avoid the interest charge of the loan. The flaw of such belief is that it ignores the opportunity cost which is the after tax interest foregone on savings.

The conventional "buy on time or pay cash" analysis seen in some mainstream personal finance textbooks, such as Gitman and Joehnk (2015), is to compare the total finance cost of the loan to the total after-tax interest earnings generated from having the money in some short-term investment assuming that the consumer has an adequate level of liquid reserves and that these reserves are being held in some type of savings account: if it costs more to borrow the money than you can earn in after tax interest on your savings, then withdraw the money from your savings to pay for the purchase; if not, you should take out a loan. Though the conventional approaches acknowledge the opportunity cost of the withdrawing savings, it ignores the time value of the interest charge of the loan and the after tax interest foregone on savings over time because the interest payments on the loan does not even out over the term of the loan but more is paid at the beginning than at the end. Such ignorance of time value of money can lead to poor buy on time or pay cash decision. Let's take a look at an example seen in Gitman and Joehnk (p. 192, 2015) concerning whether paying $\$ 12,000$ with cash or take $\$ 12,000$ 36-month, 8 percent installment loan: the textbook approach (see Worksheet 1 for detail) compares the total cost of the finance charge of the loan (with a monthly payment of $\$ 376.04$ ) which is $\$ 1537.44(=376.04 \times 36-12,000)$ to the total after-tax interest earnings generated from having the money in some type of short-term investment which is $\$ 1036.80(=12000 \times 4 \% \times(1-0.28) \times 3)$ assuming the consumer is in $28 \%$ tax bracket and earn $4 \%$ on his/her savings, then draws the conclusion that paying cash is preferred because the cost of financing (\$1537) is higher than the after tax interest earned (\$1037) on savings. Though in this example, paying cash is indeed obviously preferred because of the higher interest charge (8\%) of the loan compared to the lower interest (4\%) earned on savings, such approach can be misleading because of its ignorance of time value of money of the finance charge and interest earned on savings over time.

The flaws of the conventional approach can be easily illustrated by lowering the loan interest rate, say, from $8 \%$ to $5 \%$ in the above example. When the loan interest rate is reduced to $5 \%$, the monthly payment of the $\$ 12,000$ 36 -month loan is reduced to $\$ 359.65$, then the total finance charge over 3 years is reduced to $\$ 947.51(=359.65 \mathrm{x}$ $36-12000)$ which is lower than the total after tax interest (\$1037) earned over three years, then according to the conventional textbook approach (see Worksheet 2 for detail) "buy on time" would be preferred. However, the reality is that paying cash is still preferred because paying $\$ 12,000$ cash up front is equivalent to foregoing the amount equal to the difference between $\$ 354.29$ (36 monthly payment at 4\% annual interest rate) per month and the amount of tax paid on interest income which is lower than the loan monthly payment (\$359.65) under our 
assumption. The conventional textbook approach ignores the fact that more interest is paid at the beginning of the loan than at the end.

If we further lower the loan interest rate to $3 \%$ in the above example, then the loan monthly payment would be $\$ 348.97$. As mentioned early, under $4 \%$ interest rate on savings assumption, paying $\$ 12,000$ up front is equivalent to foregoing the amount equal to the difference between $\$ 354.29$ (36 monthly payment at $4 \%$ annual interest rate) per month and the amount of tax paid on interest income, and that difference is the 36-month annuity payment at $0.24 \%(=4 \%(1-28 \%) / 12)$ monthly interest rate which is $\$ 348.34$, thus paying cash is still preferred.

"Buy on time or pay cash" decision actually can be simply made by comparing the monthly payment of the loan to the after-tax equivalent monthly amount foregone if paying cash up front, and it is equivalent to comparing the interest rate of the loan (after tax rate if home equity loan and consumer itemizes deduction) to the after tax interest rate on savings. If the interest rate on the loan (after tax rate if home equity loan and consumer itemizes deduction) is higher than the after tax interest rate on savings, then the monthly payment of the loan would be higher than the after-tax equivalent monthly amount foregone if paying cash up front, thus paying cash is preferred, otherwise buy on time is preferred. In the previous example, as long as the interest rate on the loan is higher than the after tax interest rate on savings, which is $2.88 \%$, paying cash is always preferred, only when the interest rate on the loan is less than $2.88 \%$, taking out a loan (buy on time) is preferred.

This research note points out the common mistakes people make in "buy on time or pay cash" decision as well as seen in some mainstream personal finance texts and such analytical flaws result from the ignorance of the opportunity cost of the savings or time value of money or both. Buy on time or pay cash decision can be made by simply comparing the interest rate on the loan (after tax rate if it is home equity loan and consumer itemizes his/her deduction) to the after tax interest rate on savings: if the former is higher, pay cash is preferred, otherwise buy on time is preferred. In all analysis we assume the consumer has an adequate level of liquid reserves.

\section{Worksheet 1. Buy on Time or Pay Cash}

(Textbook Approach)

\begin{tabular}{|c|c|c|c|}
\hline \multicolumn{4}{|c|}{ Cost of borrowing (8\% interest rate on loan) } \\
\hline 1. & Terms of the loan & & \\
\hline a. & Amount of the loan & $\$ 12,000$ & \\
\hline b. & Length of the loan & 3 & \\
\hline c. & Monthly payment & $\$ 376.04$ & \\
\hline \multirow[t]{3}{*}{2.} & Total loan payments made & & \\
\hline & (monthly loan payment $x$ length of loan in month & & \\
\hline & $\$ 376.04$ per month $\quad \underline{36}$ months & & $\$ 13537.44$ \\
\hline \multirow{3}{*}{$\begin{array}{l}3 . \\
4 .\end{array}$} & Less principle amount of the loan & & $\$ 12,000$ \\
\hline & Total interest paid over the life of the loan & & \\
\hline & (line 2- line 3) & & $\$ 1537.44$ \\
\hline \multicolumn{4}{|c|}{ 5. Tax considerations: } \\
\hline \multicolumn{4}{|c|}{ - Is this a home equity loan(where interest expenses can be deducted from taxes)? } \\
\hline • & Do you itemize deductions on your federal tax return? & No & \\
\hline & $\begin{array}{l}\text { If you answer yes to both questions, then proceed to line } 6 \text {; if you answer no to either one or both of } \\
\text { the questions, then proceed to line } 8 \text { and use line } 4 \text { as the after-tax interest cost of the loan. }\end{array}$ & Yes & \\
\hline 6. & What federal tax bracket are you in? & $28 \%$ & \\
\hline 7. & Tax saved due to interest deductions & & $\$ 0.00$ \\
\hline 8. & Total after tax interest cost of the loan(line 4-line 7) & & $\$ 1537.44$ \\
\hline \multicolumn{4}{|c|}{ Cost of paying cash ( $4 \%$ interest rate on savings) } \\
\hline & $\begin{array}{l}\text { Annual interest earned on savings (annual rate of interest earned on savings } x \text { amount of loan: } 4 \% \mathrm{x} \\
12,000 \text { ) }\end{array}$ & & $\$ 480$ \\
\hline 10. & Annual after tax interest earnings (line $9 \times(1$-tax rate $)$ ) & & $\$ 346.00$ \\
\hline 11. & Total after tax interest earnings over life of loan (line $10 \mathrm{x}$ line $1 \mathrm{~b}$ : $\$ 346.00$ x 3 yeara) & & $\$ 1038.00$ \\
\hline 12. & Difference in cost of borrowing vs. cost of paying cash (line 8 - line 11) & & $\$ 499.44$ \\
\hline \multicolumn{3}{|c|}{ Basic Decision Rule: pay cash if line 12 is positive; borrow the money if line 12 is negative. } & Pay cash \\
\hline
\end{tabular}

Note. In this example, paying cash is indeed preferred because of the high loan rate and low interest rate on savings. 
Worksheet 2. Buy on Time or Pay Cash

(Textbook Approach)

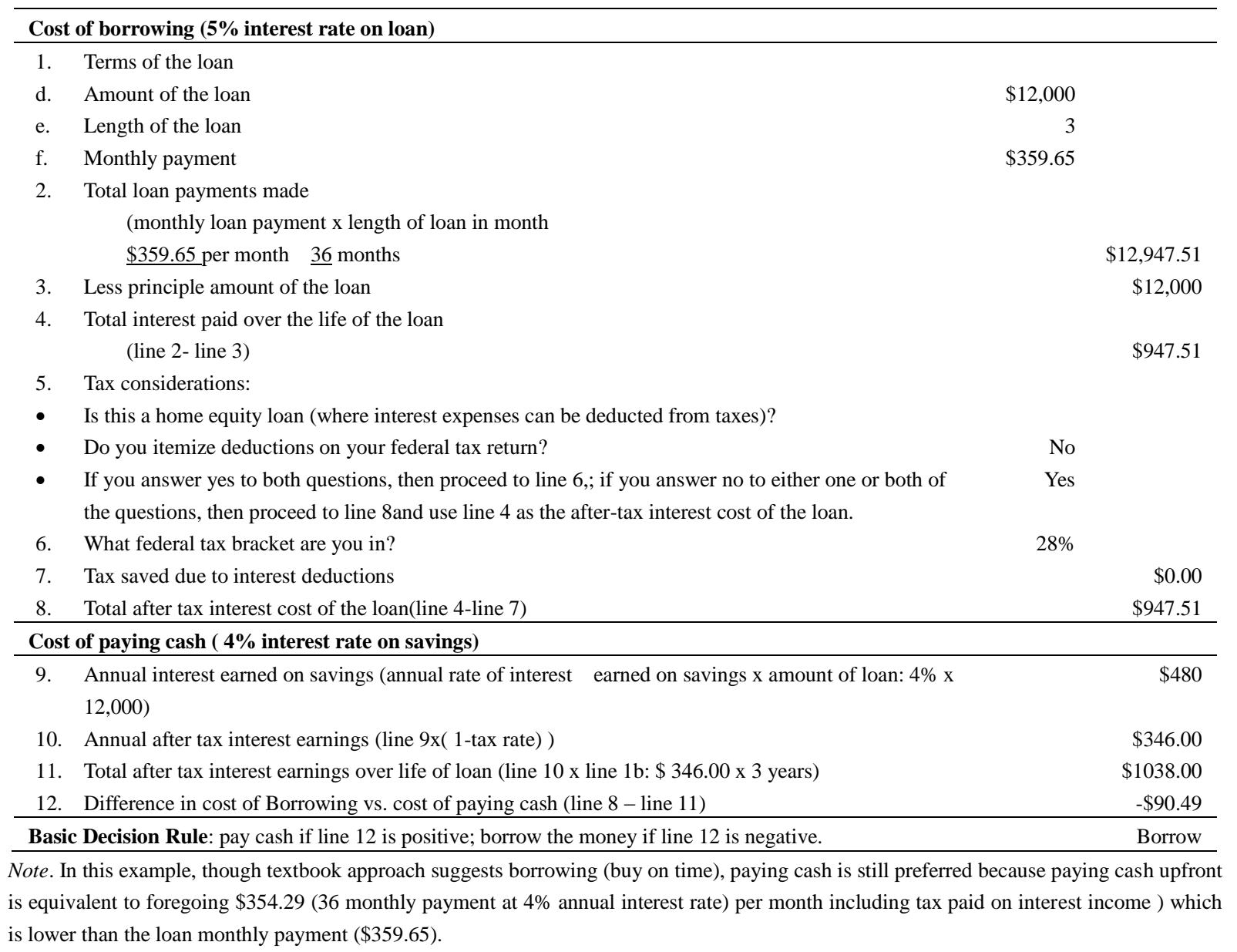

\section{Reference}

Gitman, \& Joehnk. (2015). Personal Finance.

\section{Copyrights}

Copyright for this article is retained by the author(s), with first publication rights granted to the journal.

This is an open-access article distributed under the terms and conditions of the Creative Commons Attribution license (http://creativecommons.org/licenses/by/4.0/). 